\title{
Isolation, identification, and pathogenicity tests of pathogenic bacterial associated with black body syndrome in white barramundi Lates calcarifer $\mathrm{B}$.
}

\section{Isolasi, identifikasi, serta uji patogenisitas bakteri penyebab penyakit black body syndrome pada ikan kakap putih Lates calcarifer B.}

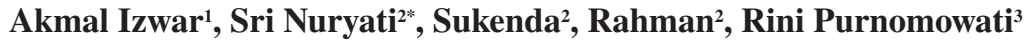 \\ ${ }^{1}$ Aquaculture Science, Department of Aquaculture, Faculty of Fisheries and Marine Sciences, IPB University, \\ Dramaga, West Java, Indonesia 16680 \\ ${ }^{2}$ Department of Aquaculture, Faculty of Fisheries and Marine Sciences, IPB University, Dramaga, West Java, \\ Indonesia 16680 \\ ${ }^{3}$ Centre for Mariculture Research Development, Lampung \\ *Corresponding author: sri.nuryati606@gmail.com
}

(Received February 1, 2018; Accepted August 21, 2019)

\begin{abstract}
This study aimed to obtain the pathogenicity of isolated bacteria from maribund barramundi Lates calcarifer with black body syndrome (BBS). Moribund barramundi was collected from the Center for Mariculture Development (BBPBL), Lampung Province. Five of pathogenic bacteria were found, i.e. Pseudomonas stutzeri L01, Vibrio harveyi, Bacillus cereus, Salinococcus roseus, and Pseudomonas stutzeri L02. The bacteria were tested for LD50 to obtain two types of high virulent bacteria to be used for the pathogenicity test. $P$. stutzeri L01 and V. harveyi were the most virulent bacteria with a bacterial density of $10^{7} \mathrm{CFU} / \mathrm{mL}$. Both bacteria were used for pathogenicity test with three treatments: injection of $P$. stutzeri L01, V. harveyi, mix $P$. stutzeri L01 and $V$. harveyi, and phosphatebuffered saline as control. Clinical symptoms showed a blackened body, bleeding under the belly, and inactive. Mortality of fish injected with P. stutzeri L01, V. harveyi and mix P. stutzeri L01 and V. harveyi was 53.33\%, $55.00 \%$, and $58.33 \%$, respectively. Erythrocyte and hemoglobin in all treatments were not significantly different $(\mathrm{P}>0.05)$. However, there was significantly different in the total leukocytes of mixed $P$. stutzeri and $V$. harveyi treatment $(\mathrm{P}<0.05)$. In conclusion, $P$. stutzeri L01, V. harveyi and mix of them resulted in black body syndrome (BBS) disease. Coinfection of $P$. stutzeri L01 and $V$. harveyi produce higher mortality than single infection.
\end{abstract}

Keywords: barramundi, black body syndrome, histopathology, pathogenicity

\begin{abstract}
ABSTRAK
Penelitian ini bertujuan mendapatkan patogenisitas bakteri dari ikan kakap putih L. calcarifer yang memiliki gejala black body syndrome (BBS). Ikan diambil dari Balai Besar Pengembangan Budidaya Laut (BBPBL), Lampung. Lima jenis bakteri patogen ditemukan, yaitu Pseudomonas stutzeri L01, Vibrio harveyi, Bacillus cereus, Salinococcus roseus, dan Pseudomonas stutzeri L02. Bakteri diuji LD50 untuk mendapatkan dua jenis bakteri virulen tinggi yang akan digunakan untuk uji patogenisitas. P. stutzeri L01 dan V. harveyi adalah bakteri paling virulen dengan kepadatan bakteri $10^{7} \mathrm{CFU} / \mathrm{mL}$. Uji patogenisitas dengan tiga perlakuan: injeksi $P$. stutzeri L01, $V$. harveyi, campuran $P$. stutzeri L01 dan V. harveyi, serta phosphate-buffered saline sebagai kontrol. Gejala klinis menunjukkan tubuh menghitam, perdarahan di bawah perut, dan pergerakan tidak aktif. Mortalitas ikan yang disuntik dengan $P$. stutzeri L01, $V$. harveyi dan campuran $P$. stutzeri L01 dan $V$. harveyi masing-masing sebesar $53,33 \%$, 55,00\%, dan 58,33\%. Eritrosit dan hemoglobin pada semua perlakuan tidak berbeda nyata $(\mathrm{P}>0,05)$. Namun, ada perbedaan yang signifikan dalam total leukosit perlakuan campuran $P$. stutzeri L01 dan $V$. harveyi $(\mathrm{P}<0,05)$. P. stutzeri L01, V. harveyi dan campuran $P$. stutzeri L01, V. harveyi dapat menyebabkan black body syndrome (BBS). Koinfeksi P. stutzeri L01 dan V. harveyi menghasilkan mortalitas lebih tinggi daripada infeksi tunggal.
\end{abstract}

Kata kunci: barramundi, black body syndrome, histopatologi, patogenisitas 


\section{INTRODUCTION}

Barramundi Lates calcarifer is one of the important species of marine culture in Southeast Asia and Australia and this increases the marine culture of barramundi (Venkatachalam et al., 2018). Barramundi intensification provided sufficient rare barramundi juvenile yet c aused a new problem. This problem appeared due to the stressful environment and fish density that would cause stress in fish. In this condition, fish exposed to stress will easily expose disease, therefore mass mortality will increase in barramundi culture.

Disease outbreak is one of the common threats against the sustainability of barramundi culture. The common cause of the disease is bacteria, viruses, or fungi. In barramundi culture, the common cause of the disease is bacteria. A previous study (Minaka et al., 2012) stated that bacteria cause disease in fish is a kind of Gramnegative bacteria. Bacteria that cause disease in Barramundi culture commonly comes from Vibrio harveyi infection. This bacteria can cause vibriosis in fish. Ransangan dan Saleem (2009) mentioned that $V$. harveyi is the main cause of vibriosis in barramundi cultured in Philipines, caused losses up to \pm US 7.4 million dollars. Economic loss in the marine culture industry due to this outbreak was estimated up to US\$ 9 billion per year and resulted in decreasing the total production of cultured fish around the world. Vibriosis disease attacks all cultured marine fish species (Krishnika \& Ramasamy, 2014).

Vibrio sp. is primer and secondary pathogen bacteria for marine fish. As primer pathogen, bacteria enter the fish body through direct contact, while as the secondary pathogen, bacteria infect fish body that has infected by other diseases (Novriadi et al., 2014). Pathogenic bacteria from Vibrio species is the agent of Vibriosis which may cause high mortality in a short time (Ode, 2012). Streptococcus sp. and Pseudomonas sp. can also cause mass mortality in cultured barramundi (Suanyuk et al., 2010; Safinska, 2018). This case was similar to mass mortality happen in Australia in 1992, mass mortality was reached 40\% in only two days (Kumaran et al., 2010). According to Sukenda et al. (2012), some of the species such as Vibrio alginolyticus, V. parahaemolyticus, V. anguillarum, and Vibrio marimus was already reported as pathogenic bacteria in fish.

In marine culture, disease infection can cause a common outbreak. Johnny and Roza (2009) reported that disease is one of the obstacles to increasing total production both for freshwater fish and marine water fish. Black body syndrome
(BBS) disease can cause a certain clinical symptom which is the fish body turns black, therefore this disease called black body syndrome (BBS) disease. Other symptoms that may appear during this disease infection are haemorrhagic, lesions, listless behavior, blackened skin, and loss of appetite. This kind of symptoms most likely shows bacterial disease. The cause of this disease is yet unknown, therefore there's an urgent need to find the cause of the disease. This study aimed to identify the cause of BBS disease and test the pathogenicity of this disease agent.

\section{MATERIALS AND METHOD}

This study was held from February 2017 to August 2017 in Main Center for Mariculture Development (BBPBL) Lampung and Fish Health Laboratory, Aquaculture Department, Faculty of Fisheries and Marine Science, IPB University.

\section{Bacteria isolation and clinical signs observation}

Fish collecting sample referred to Sugiarto et al. (2001), which is the sample selected is purposive sampling. The selected sample then was observed according to the characteristics of the tested parameters. This characteristic result was aimed at the research result in a quantitative or qualitative result. The fish sample that was obtained to identify the bacteria is fish with some clinical signs of BBS infection, such as blackened body, lesions, listless swimming behaviour, loss of appetite, and hemorrhage. This sample then was taken to Fish Health and Environment Laboratory, BBPBL Lampung. The pathogen was isolated and identified from the liver, spleen, and kidney. The organ was taken by dissected, cultured in marine agar (MA) media for 24 hours, then cultured in thiosulfate citrate bile salt sucrose (TCBS) agar media and cytophaga agar media to obtain a pure culture of bacteria.

\section{Bacteria characterization}

Bacteria characterization was done by separate bacteria colony according to its shape, edge, color, elevation, consistency, and size (Austin \& Austin, 2012). Bacteria characterization was used biochemical methods of bacteria identification (API kit) and the molecular method by using PCR of $16 \mathrm{~S}$ rRNA. The result of $16 \mathrm{~S}$ rRNA sequencing was then analyzed by BLAST software (NCBI). The $16 \mathrm{~S}$ rRNA sequencing was aimed to obtain phylogenetic within bacteria species (Drancourt et al., 2000). 


\section{Fish health status test}

Fish health status test was aimed to ensure fish used in this study was free from bacteria of BBS disease agent. The fish used in this study was a white barramundi size of 6-7 $\mathrm{cm}$ obtained from BBPBL Lampung. The external characteristics of fish used for the LD50 test and pathogenicity test should actively swim and the fish body is white. Meanwhile, the internal characteristics of some organs (liver, kidney, and spleen) should be observed in the laboratory to obtain the bacteria of $P$. stutzeri and $V$. harveyi growing within fish body organs or not. White barramundi used for the LD50 test was 12 fish for each replication and 20 fish for each replication for pathogenicity test. Fish were fed with commercial feed twice a day by at satiation. The aquarium used in this study was the size of 60 $\mathrm{cm} \times 40 \mathrm{~cm} \times 40 \mathrm{~cm}$ with a volume of $80 \mathrm{~L}$. Water used in this study was conducted to treatment by using $400 \mathrm{mg} / \mathrm{L}$ of chlorine (Rahardja et al., 2011).

\section{LD50 test}

The determination of bacteria virulence level was found by obtaining LD50 value. LD50 test was done by Reed \& Muench's method (1938), set with four different dosage, i.e $1 \times 10^{9} \mathrm{CFU} / \mathrm{mL}$, $5 \times 10^{8} \mathrm{CFU} / \mathrm{mL}, 2.5 \times 10^{8} \mathrm{CFU} / \mathrm{mL}, 5 \times 10^{7} \mathrm{CFU} /$ $\mathrm{mL}$. This bacteria concentration was obtained by the serial dilution method.

\section{Pathogenicity test}

LD50 result (fish that tested was showed some clinical symptoms like BBS symptoms) and the highest virulence test result became a reference for pathogenicity test. Healthy white barramundi juvenile was infected by single bacteria, bacteria combination, and control as it is shown in Table 1.

The determination of bacteria dosage for the challenge test was according to the previous study result. The challenge test was done by injecting $10^{7}$ $\mathrm{CFU} / \mathrm{mL}$ of $P$. stutzeri $\mathrm{L} 01$ isolate, $10^{7} \mathrm{CFU} / \mathrm{mL}$ of $V$. harveyi isolate, $10^{7} \mathrm{CFU} / \mathrm{mL}$ of combination isolate of $P$. stutzeri $\mathrm{L} 01$ and $V$. harveyi, and $0.1 \mathrm{~mL}$ of PBS as control. This injection was done by intraperitoneal. The change of internal organ (liver and kidney) tissue was showed during the infection. The changes during pathogenicity test were observed for 14 days.

\section{Observed parameters}

Clinical symptom and bacteria characterization

Bacteria isolate was obtained from white barramundi infected by BBS and then it was identified the biochemical characteristic by using API kit, meanwhile, the molecular characteristic was identified by using PCR 16S rRNA primer.

\section{Mortality and meantime of death}

The observation of fish mortality was done every day after pathogen injection. Fish mortality was calculated by using the formula below (Effendie, 1979):

$$
\text { Mortality rate }(\%)=\frac{\text { The total dead fish }}{\text { The total fish }} \times 100
$$

Fish that was already injected by pathogen was observed the behaviour every day, such as the clinical symptoms, fish mortality, and meant time to death. Meantime to death was calculated by using the formula below (Hubbert, 1980):

$$
\text { MTD }=\frac{\sum_{i-1}^{n} \text { al bi }}{\sum_{i=1}^{n} \text { bi }}
$$

$$
\begin{array}{ll}
\text { Note: } & \\
\text { MTD } & =\text { meantime to death } \\
\text { a } & =\text { mortality time (hour) } \\
\mathrm{b} & =\text { number of dead fish }
\end{array}
$$

Table 1 . The experimental design of pathogenicity test of bacterial disease attacked white barramundi juvenile

\begin{tabular}{ccc}
\hline Treatment & Note \\
\hline Control & \multicolumn{2}{c}{ Fish was injected by PBS } \\
A & Fish was injected by $P$. stutzeri L01 isolate \\
B & Fish was injected by $V$. harveyi isolate \\
Bacteria combination & Fish was injected by combination isolate of $P$. stutzeri L01 and $V$. harveyi \\
\hline Table 2. Histopathologic scoring and degrees of damage of liver and kidney & Degrees of damage \\
\hline Score & Necrosis & Normal \\
\hline 1 & $<25 \%$ of total point of view & Mild damage \\
3 & $25-<50 \%$ of total point of view & Moderate damage
\end{tabular}




\section{Histological observation}

Histological observation of tissues was observed from day $1,2,3,5,10$, and 14 after the challenge test by using hematoxylin-eosin (HE) staining. The changes of tissues were observed by counting the percentage of damage liver cell and kidney epithelium tubules, replicated three times (Mustaqien et al., 2008), followed by using the formula below:

$$
\mathrm{P}(\%)=\frac{\sum \mathrm{KS}}{\sum \mathrm{TS}} \times 100
$$

Notes:

$\mathrm{P}(\%)=$ The percentage of normal cell and cell degeneration or necrosis cell

$\Sigma \mathrm{KS}=$ The number of total normal cell and cell degeneration or necrosis cell

$\Sigma \mathrm{TS}=$ The number of total normal cell (approximately 2000 cells)

Histopathologic scoring of liver and kidney was used previous study method by Wolf et al. (2015), Wolf and Wheeler (2018) as showed below (Table 2).

\section{Hematological observation}

Blood samples were obtained at day $0,1,7$, and 14 after pathogenicity challenge test. The observed parameter of hematology were:

\section{Total erythrocyte}

Total erythrocyte was obtained by Blaxhall dan Daisley method (1973). The formula used in total erythrocyte was as follows:

$$
\underset{\left(\text { cell } / \mathrm{mm}^{3}\right)}{\sum \text { erythrocyte }}=\underset{\text { cells }}{\sum \text { Counted }} \times \frac{1}{\text { Big square volume }} \times \underset{\text { fillution }}{\text { factor }}
$$

\section{Total leukocyte}

Total leukocyte was obtained by Blaxhall dan Daisley method (1973). The formula used in total leukocyte was as follows:

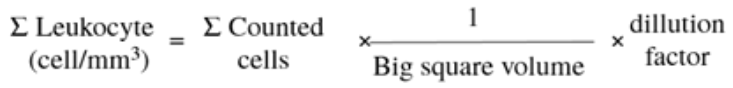

\section{Haemoglobin level}

Haemoglobin level $(\mathrm{Hb})$ measured by carried out through Sahli method (Wedemeyer \& Yasutake, 1977). The scale was read by observing the solution surface and matched with the Sahli tube scale that could be seen on the scale track (yellow scale), signifying that the haemoglobin in $\mathrm{g} / \mathrm{dL}$ blood was high.

\section{Data analysis}

This study used a randomly complete design. The data was tabulated by Microsoft Excel 2013. The mortality rate was analysed by using SPSS ver.24 with an interval of confidence of $95 \%$ and was continued by using DMRT (Duncan's multiple range test). Tissue histology was analysed by using the Kruskal-Wallis test and was continued by using the Mann-Whitney test.

Table 3. The results of bacteria biochemical identification found in white barramundi ( $L$. calcarifer

\begin{tabular}{cccc}
\hline Bacteria & Gram characterization & Biochemical identification & PCR 16S rRNA identification \\
\hline 1 & - & Pseudomonas stutzeri $87.7 \%$ & Pseudomonas stutzeri L01 \\
2 & - & Vibrio harveyi $88.5 \%$ & Vibrio harveyi \\
3 & + & Bacillus cereus $99 \%$ & Bacillus cereus \\
4 & - & - & Salinococcus roseus \\
5 & - & Pseudomonas stutzeri $99.3 \%$ & Pseudomonas stutzeri L02 \\
\hline
\end{tabular}

Table 4. The result of five bacteria density in LD50 of white barramundi juvenile

\begin{tabular}{ccc}
\hline Bacteria & Mortality (\%) & LD50 $(\mathrm{CFU} / \mathrm{mL})$ \\
\hline Pseudomonas stutzeri L01 & $64.58 \pm 0.07^{\mathrm{d}}$ & $8.4 \times 10^{7}$ \\
Vibrio harveyi & $81.25 \pm 0.35^{\mathrm{e}}$ & $6.2 \times 10^{7}$ \\
Bacillus cereus & $54.17 \pm 0.24^{\mathrm{c}}$ & $2.9 \times 10^{8}$ \\
Salinococcus roseus & $43.75 \pm 0.57^{\mathrm{b}}$ & $4.2 \times 10^{8}$ \\
Pseudomonas stutzeri L02 & $41.67 \pm 0.66^{\mathrm{a}}$ & $3.7 \times 10^{8}$ \\
\hline
\end{tabular}




\section{RESULTS AND DISCUSSION}

\section{Result}

\section{Bacteria characterization}

Five bacteria isolates were obtained from white barramundi (Table 3). Then these five bacteria isolates were characterised through bacteria biochemical identification using API kit and PCR $16 \mathrm{~S}$ rRNA primer.

\section{LD50 test}

The difference of bacteria type affects bacteria density that causes mass mortality in fish, therefore, it requires LD50 toward the bacteria. LD50 determination was done by calculated total mortality of fish in the first 24 hours after infection through injection (Table 4). However, the mortality will probably occur in the first 24 hours due to the latest infection. Therefore, some previous studies explained that poisoning symptoms should be observed until seven days (Angelina, 2008). The results showed that $P$. stutzeri $\mathrm{L} 01$ and $V$. harveyi had highest virulency due to its density reached $8.4 \times 10^{7} \mathrm{CFU} / \mathrm{mL}$ and $6.2 \times 10^{7} \mathrm{CFU} / \mathrm{mL}$ and both could cause $50 \%$ mortality in fish (Table 4 ).

\section{Pathogenicity test}

Bacteria pathogenicity can be seen when the bacteria caused mortality in fish. Meantime to death of white barramundi juvenile had different result among others (Table 5).

Fish that were infected by bacteria combination (P. stutzeri L01 and $V$. harveyi) infection has the longest mean time to death comparing to single infection ( $\mathrm{A}$ and $\mathrm{B}$ ). Despite this, it had the longest mean time to death, yet the mortality was higher compared to a single infection. Moreover, bacteria combination infection was also caused worse damage to the macroscopic body and internal organ comparing to other treatments, whereas, the control treatment had no mortality and none mean time to death and it was all normal.

\section{Histopathologic scoring}

Total histopathologic score of liver and kidney of each treatment was different (Table 6). The histopathologic score of the liver among the three treatments were different $(\mathrm{P}<0.05)$ than the control. $P$. stutzeri L01 treatment was not significantly different $(\mathrm{P}>0.05)$ than $V$. harveyi treatment, yet it was significantly different $(\mathrm{P}<0.05)$ compared to bacteria combination treatment.

Table 5. Macroscopic condition of fish body, internal organ, and mean time to death

\begin{tabular}{|c|c|c|c|c|}
\hline Treatments & $\begin{array}{l}\text { Mortality } \\
(\%)\end{array}$ & $\begin{array}{l}\text { MTD } \\
\text { (hour) }\end{array}$ & $\begin{array}{l}\text { Macroscopic condition of } \\
\text { fish body }\end{array}$ & $\begin{array}{l}\text { Macroscopic condition of } \\
\text { internal organ }\end{array}$ \\
\hline Control & 0 & 0 & The body was whitened & $\begin{array}{l}\text { Liver: redden } \\
\text { Kidney: dusky red }\end{array}$ \\
\hline $\begin{array}{c}\text { A } \\
\text { P. stutzeri L01 }\end{array}$ & $53.33 \pm 0.33^{\mathrm{a}}$ & 64.76 & $\begin{array}{c}\text { The body was blackish, } \\
\text { lession in lower abdoment, } \\
\text { dropsy }\end{array}$ & $\begin{array}{l}\text { Liver: pale red } \\
\text { Kidney: dusky red }\end{array}$ \\
\hline $\begin{array}{c}\mathrm{B} \\
\text { V. harveyi }\end{array}$ & $55.00 \pm 0.33^{\mathrm{a}}$ & 67.92 & $\begin{array}{c}\text { The body was blackish, } \\
\text { lession in lower abdoment, } \\
\text { dropsy }\end{array}$ & $\begin{array}{c}\text { Liver: pale red } \\
\text { Kidney: dusky red } \\
\text { Intestine: yellowish fluids. }\end{array}$ \\
\hline $\begin{array}{l}\mathrm{B} \text { a } \mathrm{c} \mathrm{t} \text { e } \mathrm{r} \mathrm{i} \text { a } \\
\text { combination } \\
\text { (P. stutzeri } \mathrm{L} 01 \text { and } \\
\quad V \text {. harveyi })\end{array}$ & $58.33 \pm 0.67^{b}$ & 70.69 & $\begin{array}{l}\text { The body was blackish, } \\
\text { lession in lower abdoment, } \\
\text { dropsy }\end{array}$ & $\begin{array}{c}\text { Liver: pale red } \\
\text { Kidnet: dusky red } \\
\text { Intestine: state of decay and } \\
\text { had yellowish fluids. }\end{array}$ \\
\hline
\end{tabular}

Table 6. Total histopathologic score of liver and kidney of juvenile white barramundi using Kruskal Wallis and Mann Whitney analysis

\begin{tabular}{ccc}
\hline \multirow{2}{*}{ Treatments } & \multicolumn{2}{c}{ Histopathologic score } \\
\cline { 2 - 3 } & Liver & Kidney \\
\hline Control & $1.00 \pm 0.00^{\mathrm{a}}$ & $1.00 \pm 0.00^{\mathrm{a}}$ \\
$P$. stutzeri L01 & $2.00 \pm 0.34^{\mathrm{b}}$ & $1.67 \pm 0.34^{\mathrm{b}}$ \\
V. harveyi & $2.17 \pm 0.00^{\mathrm{bc}}$ & $2.00 \pm 0.17^{\mathrm{bc}}$ \\
Campuran & $2.39 \pm 0.10^{\mathrm{c}}$ & $2.39 \pm 0.26^{\mathrm{c}}$ \\
\hline
\end{tabular}

Different superscript in the same column showed significantly different result $(\mathrm{P}<0.05)$ 

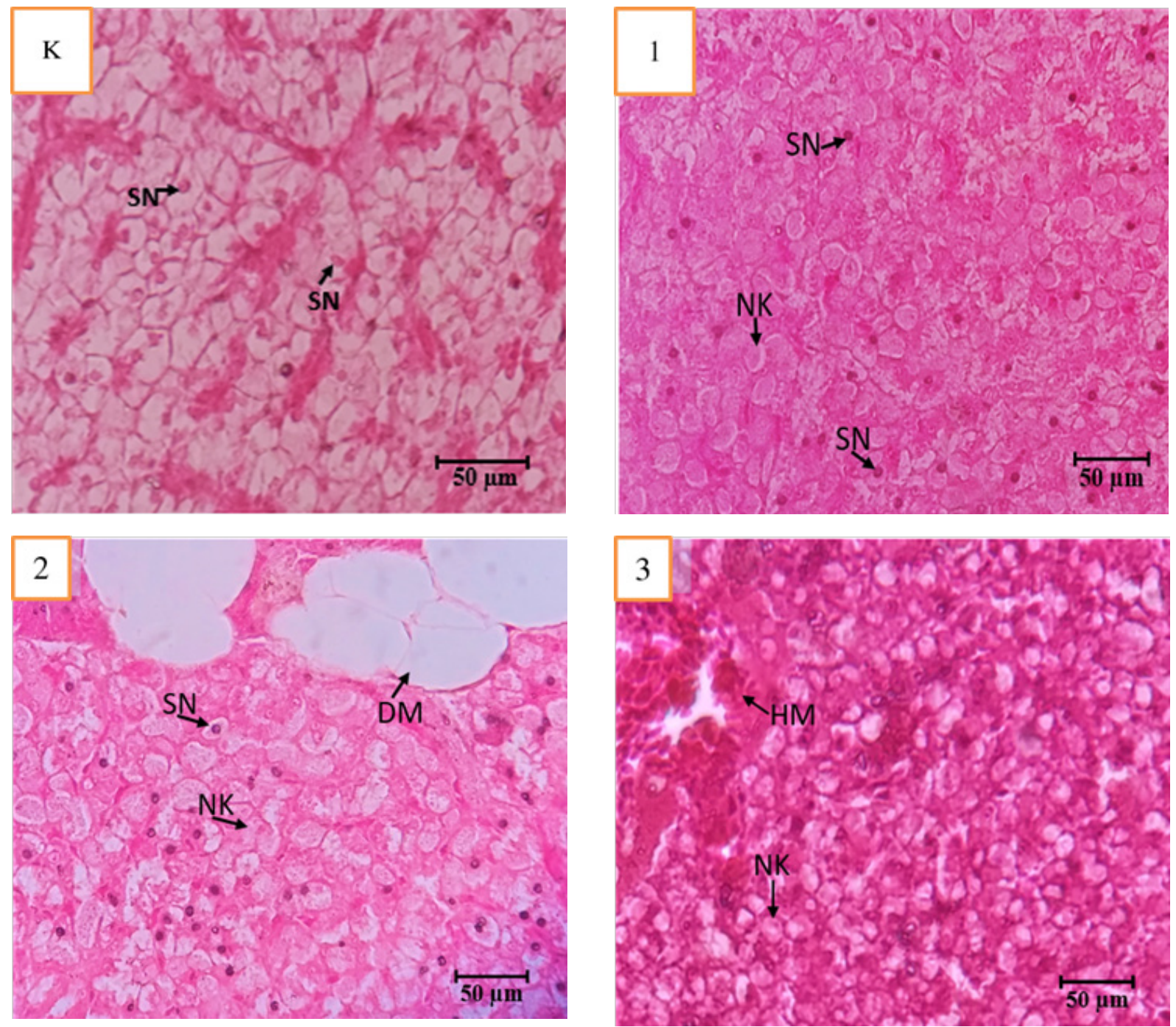

Figure 1. Microscopic condition of liver: control (K), infected with P. stutzeri L01 (1), infected with V. harveyi (2), and infected with bacteria combination (3). Note: (SN) Normal cell; (NK) necrosis; (MM) melanomacrophage; (DM) lipid degeneration; (HM) hemorrhage. The liver condition was observed by using microscope with 400 times magnification.

\section{Histological observation of liver}

The microscopic condition of the liver (Figure 1) between control treatment, P. stutzeri L01 treatment, $V$. harveyi treatment, and bacteria combination treatment was different. The worst condition of the liver was showed in bacteria combination treatment, shown some necrosis and haemorrhage.

\section{Hematological observation}

The condition of fish hematology in each treatment had a different result for each parameter (Table 7). Total leukocyte among P. stutzeri L01, $V$. harveyi, and bacteria combination treatment were higher than control. The highest total leukocyte value was obtained in bacteria combination treatment.

\section{Discussion}

Disease in fish is a complex process involving the interaction of a pathogen bacterium, a susceptible fish host and environmental factors. Bacterial fish infection is normally caused by opportunistic bacteria, facultative pathogen bacteria, or obligate pathogen bacteria. Opportunistic bacteria invade immunosuppressed fish, while atypical fish environmental stressors, such as those occurring in intensive aquacultural rearing (hypoxia, abnormal $\mathrm{pH}$, and high population density) generate an optimal setting for such pathogens to thrive (Derome et al., 2016). In general, the survival, multiplication, interaction and pathogenicity of the bacteria require that the pathogen and host exist in the same environment and that the pathogen (1) successfully invades the host, (2) finds a nutritionally compatible niche in the host body, (3) can overcome 
Table 7. The hematology of white barramundi at day $0,1,7$, and 14 after bacteria injection

\begin{tabular}{|c|c|c|c|c|}
\hline Observation time & Treatments & $\begin{array}{c}\sum \text { Erythrocyte } \\
\left(\times 10^{6} \text { cell } / \mathrm{mm}^{3}\right)\end{array}$ & $\begin{array}{c}\sum \text { Leukocyte } \\
\left(\times 10^{4} \text { cell } / \mathrm{mm}^{3}\right)\end{array}$ & $\begin{array}{c}\mathrm{Hb} \\
(\mathrm{g} / \mathrm{dL})\end{array}$ \\
\hline Day 0 & Before injection & $3.81 \pm 0.00^{\mathrm{a}}$ & $3.15 \pm 0.00^{\mathrm{a}}$ & $14.00 \pm 0.00^{\mathrm{a}}$ \\
\hline \multirow[t]{4}{*}{ Day 1} & Control & $3.78 \pm 0.10^{\mathrm{b}}$ & $3.20 \pm 0.05^{\mathrm{a}}$ & $14.00 \pm 0.58^{\mathrm{b}}$ \\
\hline & P. stutzeri & $3.73 \pm 0.04^{\mathrm{b}}$ & $4.45 \pm 0.16^{\mathrm{b}}$ & $14.00 \pm 0.00^{\mathrm{b}}$ \\
\hline & $V$. harveyi & $3.34 \pm 0.09^{a}$ & $4.85 \pm 0.24^{\mathrm{bc}}$ & $13.00 \pm 1.00^{\mathrm{a}}$ \\
\hline & Bacteria combination & $3.35 \pm 0.07^{\mathrm{a}}$ & $5.25 \pm 0.13^{c}$ & $13.33 \pm 0.58^{\mathrm{a}}$ \\
\hline \multirow[t]{4}{*}{ Day 7} & Control & $3.80 \pm 0.10^{\mathrm{b}}$ & $3.25 \pm 0.06^{\mathrm{a}}$ & $12.00 \pm 0.00^{\mathrm{b}}$ \\
\hline & P. stutzeri & $3.72 \pm 0.20^{\mathrm{b}}$ & $4.95 \pm 0.07^{\mathrm{b}}$ & $12.00 \pm 0.00^{\mathrm{b}}$ \\
\hline & V. harveyi & $3.45 \pm 0.19^{\mathrm{a}}$ & $5.80 \pm 0.17^{\mathrm{b}}$ & $11.67 \pm 0.58^{\mathrm{ab}}$ \\
\hline & Bacteria combination & $3.32 \pm 0.14^{\mathrm{a}}$ & $7.45 \pm 0.17^{\mathrm{c}}$ & $11.00 \pm 0.00^{\mathrm{a}}$ \\
\hline \multirow[t]{4}{*}{ Day 14} & Control & $3.89 \pm 0.18^{\mathrm{ab}}$ & $3.45 \pm 0.15^{\mathrm{a}}$ & $12.00 \pm 0.58^{\mathrm{b}}$ \\
\hline & P. stutzeri & $3.83 \pm 0.21^{\mathrm{ab}}$ & $4.25 \pm 0.05^{\mathrm{b}}$ & $12.00 \pm 0.00^{\mathrm{b}}$ \\
\hline & V. harveyi & $3.68 \pm 0.10^{\mathrm{a}}$ & $4.60 \pm 0.09^{\mathrm{bc}}$ & $12.00 \pm 0.00^{\mathrm{b}}$ \\
\hline & Bacteria combination & $3.60 \pm 0.26^{\mathrm{a}}$ & $4.85 \pm 0.12^{c}$ & $11.00 \pm 0.00^{\mathrm{a}}$ \\
\hline
\end{tabular}

Different superscript in the same observation time and column showed significantly different result $(\mathrm{P}<0.05)$.

the host immune response, (4) can use the host cell mechanisms to multiply, (5) can spread to a new host and, finally, (6) possesses a resistance strategy. The virulence and pathogenicity mechanisms developed by bacteria may be associated with the bacterial structure (membrane, fimbriae, pili, etc), to the extracellular products and the host cell defence capacities (Hamed et al., 2018). The result of the LD50test showed that $P$. stutzeri and $V$. harveyi were the most virulent due to their ability to kill $50 \%$ of fish with the lowest bacteria concentration $\left(10^{7} \mathrm{CFU} / \mathrm{mL}\right)$. $B$. cereus and S. roseus have an LD50 concentration of $10^{8} \mathrm{CFU} / \mathrm{mL}$, meanwhile, $P$. stutzeri $\mathrm{L} 02$ has the highest LD50 concentration, it was $10^{\circ} \mathrm{CFU} / \mathrm{mL}$. According to the LD50 test result, the bacteria that used for pathogenicity tests in white barramundi juvenile were $P$. stutzeri L01 and $V$. harveyi.

$P$. stutzeri $\mathrm{L} 01$ and $V$. harveyi are common bacteria in tropical seawater and are dominant microflora (Alikunhi et al., 2016; Aguirre et al., 2017). Park et al. (2013) and Deng et al. (2014) stated that $P$. stutzeri was widely distributed to the environment, was occupied in various ecology and was found as an opportunistic pathogen in humans. P. stutzeri participates in the denitrification process (biological nitrogen removal from wastewater). P. stutzeri that found in human, soil, and seawater is known to have had a different strain and different typical metabolic. P. stutzeri is capable to survive under a low oxygen level and has an important role in the denitrification process of water (Diep et al., 2009). P. stutzeri is a zoonosis (this type of disease passes from an animal to a human), yet it has lower virulence (Reisler \& Blumberg, 1999).
Two bacteria with lowest LD50 then was tested the pathogenicity by checking out the mean time to death, macroscopic, and microscopic fish anatomy (the histology of liver and kidney of fish infected by pathogen bacteria). White barramundi juvenile in bacteria combination treatment has a mortality of $58.33 \%$ (highest mortality) and showed significantly different results with $V$. harveyi treatment $(55 \%)$ and P. stutzeri L01 treatment (53.33\%), meanwhile there was no mortality in the control treatment $(\mathrm{P}<0.05)$. This result was directly proportional to the mean time to death of bacteria combination treatment, it was 75.12 hours, it was longer than $V$. harveyi treatment (68.59 hours) and P. stutzeri treatment (61.05 hours).

Clinical symptoms in the fish body were characterized by the appearance of hemorrhage in the lower abdomen, dropsy, and ulcer (as found as in chronic disease). This was in line as Ode (2011) stated that fish attacked by vibriosis has some symptoms, such as dropsy and ulcer in some parts of the body. The observation of each macroscopic condition of the liver and kidney after bacteria injection was different. The liver of white barramundi juvenile that has been injected by $P$. stutzeri was turned pale, the kidney was turned dusky red, the intestine was yellowish. The condition of liver and kidney in all treatments of this study were shown in the same condition as mentioned before.

The damage found in three treatments were haemorrhage and necrosis. The total histopathologic score of liver and kidney for 14 
days observation was different among treatments than control. The histopathologic score of control was 1.00 (the necrosis was $<25 \%$ ), lower than treatment A that was 1.94 (the necrosis was $<25 \%$ ). The histopathologic score of treatment B was 2.17 (the necrosis was $25-<50 \%$ ), lower than combination treatment with a histopathologic score of 2.3917 (the necrosis was $25-<50 \%$ ). These scores were comparable with histopathologic of the liver in every treatment. The liver and kidney in the control treatment were observed normal (Figure 1), meanwhile, liver and kidney in other treatments were showed some lesions and damage.

Maharajan et al. (2016) and Sari et al. (2016) stated that the liver became the object that most often examined because the liver is the target organ to obtain an environmental impact and a correlation between environmental factors and structure and function of hepatic cells. Biotoxin, parasite, bacteria, some pollutants such as pesticides and hydrocarbon are sometimes found in the liver. Bacteria that were injected into the fish body is common microflora found in seawater (opportunistic bacteria). This bacteria attacks fish when the water quality is decreased. P. stutzeri is a bacteria with a wide geographical area and is known as nitrification bacteria in water (Diep et al., 2009; Hastuti, 2011). The emergence of this bacteria as a pathogen is suspected as a result of water quality reduction in Lampung, therefore the amount of this bacteria is excess.

Hematology parameter has been used as a fish health status indicator in some fish species (Santos et al., 2009; Adedeji, 2010; Akinrotimi et al., 2012; Sayed \& Moneeb, 2015). Furthermore, blood is one of the defence components from the attack of the disease. Blood contains antimicrobial that is actively build an innate immune system (Dong et al., 2016). Hematology of white seabass juvenile that was infected by bacteria showed nearly the same. The statistical analysis result showed that the total erythrocyte was not significantly different within treatments on day 1 and day 7 , yet the results decreased continuously. On day 14, within treatment $\mathrm{A}, \mathrm{B}$, combination treatment, and control were showed a significantly different result. The decrease in these total erythrocyte in treatment $\mathrm{B}$ and combination treatment was related to the characteristic of bacteria. $V$. harveyi has hemolysin toxin that can cause lysis of red blood cells by destroying their cell membrane (Suriyani, 2013).
Total leukocyte of white barramundi juvenile that infected by bacteria was increased after 24 - hour postinjection. The total leukocyte of $P$. stutzeri L01, $V$. harvey $i_{s}$ and combination were significantly different among treatments with the control. The highest total leukocyte count was found in bacteria combination treatment. Similarly, on day 7 after injection, the total leukocyte count of each treatment was increased continuously and was showed significantly different results among treatments. This increase of total leukocyte since day 1 to day 7 showed that the fish body has responded to antigens. At day 14 after injection, total leukocyte count was decreased, it has shown that there were no mortality found at day 8 to day 14. This result was in line with the statements of Martins et al. (2009) and Shahi et al. (2014) that the increase of infection intensity caused by pathogen could trigger higher production of leukocyte. Moreover, the increase of leukocyte cells is reflecting on the efficacy of the nonspecific immune system. Mangunwardoyo et al. (2010), Priyatna et al. (2011) and Kurniawan et al. (2014) stated that pathogen in the fish body could activate polymorphonuclear leukocyte cells (melanomacrophage, monocyte, and neutrophils) that plays a role as phagocytic cells. Therefore, the total leukocyte count is often used as an indicator of fish health status

Haemoglobin level of each treatment was increased at day one after injection. This increasing was caused by the response of the body against bacteria. The haemoglobin level of bacteria combination treatment at day seven was significantly different among P. stutzeri L01 treatment and control.This was caused by day seven to day 14, there was not found any mortality in both treatment and the fish condition was started recovering, meanwhile, in bacteria combination treatment was still found mortality. Similarly, at day-1, the haemoglobin level of mixed bacteria treatment was lower compared to other treatments $(\mathrm{P}<0.05)$. Haemoglobin is a nutrient source for bacteria (Pishchany \& Skaar, 2012). This showed that the decrease in haemoglobin is caused by bacteria infection. The result of this study was in line with the previous study by Bailone et al. (2010) which stated that the decrease in haemoglobin level is caused by bacteria infection inside the host's body.

The bacteria combination treatment showed the highest cell damage in white barramundi juvenile. The clinical symptoms include the body color turned black, haemorrhage, ulcer, and the internal organ 
was rotten. These clinical symptoms were concluded as black body syndrome (BBS) disease. Similarly, the histopathologic score of the liver in bacteria combination treatment was 2.39, in which this was the highest score among other treatments. Moreover, the bacteria combination treatment had the highest total leukocyte compared to single bacteria treatment. This was showed that the infection of two bacteria, simultaneously, would cause loss of fish health faster than single bacteria infection. Besides that, high fish mortality showed that the fish immunity could not fight against two bacteria infection simultaneously.

\section{CONCLUSION}

The results of bacteria isolation and characterization from white barramundi juvenile showed that black body syndrome (BBS) disease is caused by five different bacteria, such as $P$. stutzeri L01, V. harveyi, $B$. cereus, $S$. roseus, and $P$. stutzeri L02. The result of the LD50 test showed that $P$. stutzeri L01 and $V$. Harveyi with the lowest density could cause BBS disease in white barramundi juvenile. Furthermore, the result of the pathogenicity test showed that the infection caused by bacteria combination ( $P$. stutzeri L01 and $V$. harveyi) infection had the highest pathogenicity than single bacteria infection.

\section{REFERENCES}

Adedeji OB. 2010. Acute effect of diazinon on blood plasma biochemistry in the African catfish Clarias gariepinus. Journal of Clinical Medicine \& Research 2: 1-6.

Aguirre LDG, Romera SY, Munoz SG, Maresca MR. 2017. First description of wound infection with Vibrio harveyi in Spain. New Microbe and New Infect 19: 15-16.

Akinrotimi OA, Agokei EO, Aranyo AA. 2012. Changes in blood parameters of tilapia guineensis exposed to different salinity levels. Journal of Environmental Engineering \& Technology 1: 4-12.

Alikunhi NM, Batang ZB, Aljahdali HA, Aziz AM, Suwailem AL. 2016. Culture dependent bacteria in commercial fishes: Qualitative assessment and molecular identification using 16S rRNA gene sequencing. Saudi Journal of Biological Sciences. 10: $1-27$.

Angelina M. 2008. Penentuan LD50 daun cinco Cyclea barbata Miers. pada mencit. Jurnal Makara Sains 12: 23-26.
Austin B, Austin DA. 2012. Bacterial Fish Pathogens: Disease of farmed and wild fish $4^{\text {th }}$ ed. London (GB): Springer Inc.Bailone RL, Martins ML, Mouriño JLP, Vieira FN, Pedrotti FS, Nunes GC, Silva BC. 2010. Hematology and agglutination titer after polyvalent immunization and challenge with Aeromonas hydrophila in Nile tilapia Oreochromis niloticus. Archivos de Medicina Veterinaria 42: 221-227.

Blaxhall PC, Daisley KW. 1973. Reutine haemotologycal methods for use with fish blood. Journal Fish Biology. 5: 577-581.

Deng B, Fu L, Zhang X, Zheng J, Peng L, Sun J, Zhu H, Wang Y, Li W, Wu X, Wu D. 2014. The denitrification characteristics of Pseudomonas stutzeri SC221-M and its application to water quality control in grass carp aquaculture. Plos One 9: 1-20.

Derome N, Gauthier J, Boutin S, Llewellyn M. 2016. Bacterial opportunistic pathogens of fish. Advances Environmental Microbiology. 3: 81-108.

Diep CN, Cam PM, Vung NH, Lai TT, My NTX. 2009. Isolation of Pseudomonas stutzeri in wastewater of catfish fish-pondsin the Mekong Delta and its application for wastewater treatment. Bioresource Technology 100: 3787-3791.

Dong M, Sze WT, Wei S, Doris WT, Au, Yun WL. 2016. Characterization of the interactions between fish serum proteins and pathogenic bacteria by using label-free quantitative proteomics. Journal Immunology 196: 245-268.

Drancourt M, Bollet C, Carlioz A. 2000. 16S ribosomal DNA sequence analysis of a large collection of environmental and clinical unidentifiable bacterial isolates. Journal of Clinical Microbiology 38: 3623-3630.

Effendie MI. 1979. Metode Biologi Perikanan. Jakarta: Gramedia Pustaka Utama.

Hamed SB, Paiva MJTR, Tachibana L, Dias DC, Ishikawa CM, Esteban MA. 2018. Fish pathogen bacteria: Adhesion, parameters influencing virulence and interaction with host cells. Fish and Shellfish Immunology. 80: $550-562$.

Hastuti YP. 2011. Nitrifikasi dan denitrifikasi di tambak. Jurnal Akuakultur Indonesia 10: 89-98.

Hubbert JJ. 1980. Bioassay. Kendall/Hunt Publishing Company. Lowa. USA.

Johnny F, Roza D. 2009. Kasus infeksi irido 
pada benih ikan kerapu pasir, Epinephelus corralicola di hatchery. Journal of Fisheries and Science 11: 8-12.

Krishnika, A. dan P. Ramasamy. 2014. Legenidium sp. Infection in the larval stages of the freshwater prawn Macrobrachium rosenbergii (de Man). Indian Journal of Fisheries 61: 90-96.

Kumaran S, Deivasigamani B, Alagappan KM, Sakthivel M, Guru PS. 2010. Isolation and characterization of Pseudomonas sp. KUMS3 from Asian sea bass Lates calcarifer with fin rot. World Journal of Microbiology and Biotechnology 26: 359-363.

Kurniawan A, Sarjito, Prayitno SB. 2014. Pengaruh pemberian ekstrak daun binahong Anredera cordifolia pada ikan terhadap kelulushidupan dan profil darah lele dumbo Clarias gariepinus yang diinfeksi Aeromonas caviae. Journal of Aquaculture Management and Technology 3: 76-85.

Maharajan A, Kitto MR, Paruruckumani PS, Ganapiriya V. 2016. Histopathology biomarker respons in Asian sea bass, Lates calcarifer (Bloch) exposed to copper. The Journal of Basic and Applied Zoology 77: 21-30.

Mangunwardoyo W, Ismayasari R, Riani E. 2010. Uji patogenitas dan virulensi Aeromonas hydrophila strain pada ikan nila Oreochromis niloticus Lin. melalui postulat Koch. Jurnal RIS Akuakultur 5: 245-255.

Martins ML, Vieira FP, Jeronimo GT, Mourino JLP, Dotta G. 2009. Leukocyte response and phagocytic activity in Nile tilapia experimentally infected with Enterococcus sp. Fish Physiology and Biochemistry 35: 219222.

Minaka A, Sarjito S, Hastuti. 2012. Identifikasi agensi peyebab dan profil darah ikan gurami Osphronemus gourami yang terserang penyakit bakteri. Semarang. Jurnal of Aquaculture Management and Technology 1: 249-263.

Novriadi, Romi, Ibtisam, Erick OO, Harry A, Shane W, Haw KB. 2014 Aquaherb conditioners: the silver bullet for Asian seabass Lates calcarifer and silver pompano Trachinotus blochii protection against Vibriosis. International Journal of Advanced Research 2: 275-284.

Ode I. 2011. Identifikasi ekspresi protein reseptor organ otak ikan kerapu tikus Cromileptes altivelis pada infeksi vibriosis. Jurnal MIPA, Kependidikan, dan Terapan 3: 216-224.
Ode, I. 2012. Patologi bakteri Vibrio sp. pada ikan. Jurnal MIPA, Kependidikan, dan Terapan 3: 355-359.

Park SW, Back JW, Lee SW, Song JH, Shin CH, Kim GE, Kim MJ. 2013. Successful antibiotic treatment of Pseudomonas stutzeri induced peritonitis without peritoneal dialysis catheter removal in continuous ambulatory peritoneal dialysis. Kidney Research and Clinical Practice 32: 81-83.

Pishchany G, Skaar EP. 2012. Taste for Blood: Hemoglobin as a Nutrient Source for Pathogens. Journal Plos One 8: 1-4.

Priyatna R, Indarjulianto S, Kurniasih. 2011. Aeromonas salmonicida infection of different areas in Indonesia on carp Cyprinus carpio. Biota 16: 287-297

Rahardja BS, Sari DS, Alamsjah MA. 2011. Effect of use of snail meat Achatina fulica for artificial diet on growth, food convertion and survival rate catfish Pangasius pangasius. Jurnal Ilmu Perikanan dan Kelautan 3: 117-122

Ransangan J, Saleem M. 2009. Identification of Vibrio harveyi isolated from diseased asian seabass Lates calcarifer by use of $16 \mathrm{~S}$ ribosomal DNA sequencing. Journal of Aquatic Animal Health 21: 150-155.

Reed LJ, Muench H. 1938. A Simple method of estimating fifty percent endpoints. American Journal of Epidemiology 27: 493-497.

Reisler RB, Blumberg H. 1999. Community acquired Pseudomonas stutzeri vertebral osteomyelitis in a previously healthy patient: case report and review. Clinical Infectious Disease 29: 667-669.

Safinska AP. 2018. Contemporary threats of bacterial insfection in freshwater fish. Journal of Veterinary Research 62: 261-267.

Santos AA, Ranzani Paiva MJT, Veiga ML, Faustino L, Egami MI. 2009. Hematological parameters and phagocytic activity in fat snook Centropomus parallelus bred in captivity. Fish \& Shellfish Immunology 33: 953-961.

Sari W, Okavia IW, Cerianna R, Sunarti. 2016. Struktur mikroskopis hati ikan seurukan Osteochilus vittatus dari Sungai Krueng Sabee Kabupaten Aceh Jaya yang tercemar limbah penggilinggan bijih emas. Jurnal Biotik 4: 33-40.

Sayed AEH, Moneeb RH. 2015. Hematological and biochemical characters of monosex tilapia Oreochromis niloticus Linnaeus 1758 
cultivated using methyltestosterone. The Journal of Basic \& Applied Zoology 72: 3642.

Shahi N, Mallik SK, Sarma D. 2014. Leukocyte response and phagocytic activity in common carp, Cyprinus carpio experimentally infected with virulent Aeromonas allosaccharophila. Journal of Ecophysiology and Occupational Health 14: 66-70.

Suanyuk N, Sukkasame N, Tanmark N, Yoshida T, Itami T, Thune RL, Tantikitti C, Supamattaya K. 2010. Streptococcus iniae infection in cultured Asian sea bass Lates calcarifer and red tilapia Oreochromis sp. in Southern Thailand. Journal of Science and Technology 32: 341-348.

Sugiarto, Siagian D, Sunaryanto LT, Oetomo DS. 2001. Teknik Sampling. Gramedia Pustaka Umum. Jakarta.

Sukenda, Widanarni, Haris E. 2012. Isolation and characterization of pathogenic Vibrio on tiger grouper Epinephelus fuscoguttatus. Jurnal Akuakultur Indonesia 11: 28-37.

Suriyani I, Kadriah IAK, Kuruseng I. 2013. Detection of Vibrio harveyi using hemolysin primer in tiger shrimp Penaeus monodon. Jurnal Akuakultur Indonesia 12: 101-105.

Venkatachalam S, Kandasamy K, Krishnamoorthy I, Narayanasamy R. 2018. Survival and growth of fish Lates calcarifer under integrated mangrove-aquaculture and open-aquaculture systems. Aquaculture Report 9: 18-24.

Wedemeyer IWT, Yasutake WT. 1977. Clinical methods for the assessment of the effect on environmental stress on fish health. Journal Fish \& Wildlife Service 89: 1-17.

Wolf JC, Baumgartner WA, Blazer VS, Camus AC, Engelhardt J A, Fournie JW, Frasca SJ, Groman DB, Kent M, Khoo LH, Law JM, Lombardini ED, Fehlert CR, Segner HE, Smith SA, Spitsbergen JM, Weber K, Wolfe MJ. 2015. Nonlesions, misdiagnoses, missed diagnoses, and other interpretive challenges in fish histopathology studies: A Guide for Investigators, Authors, Reviewers, and Readers. Toxicologic Pathology 43: 297-325.

Wolf JC, Wheeler JR. 2018. A critical review of histopathological findings associated with endocrine and non-endocrine hepatic toxicity in fish models. Aquatic Toxicology 197: 6078. 